\title{
PESANTREN AND SOCIAL EMPOWERMENT: A STUDY OF ITS IMPLEMENTATION PROCESS
}

\author{
Sri Widayanti \\ STPMD “APMD” Yogyakarta \\ Jl. Timoho No. 317, Baciro, Gondokusuman, Yogyakarta, Indonesia \\ Email:widisriwidayanti@gmail.com
}

Siti Muawanah

Balai Litbang Agama Semarang

Jl. Untung Suropati Kav. 70, Bambankerep, Ngaliyan, Semarang, Indonesia

Email: analitbang@gmail.com

Article received January $8^{\text {th }}, 2021$; Article revised March 31 ${ }^{\text {th }}, 2021$; Article approved May $8^{\text {th }}, 2021$

\begin{abstract}
The discussion of the implementation process of social empowerment, which is based on religious belief and critical analysis of social problems, is an interesting discourse. Various faith-based organizations, including pesantren in Indonesia, attempt to contribute to social empowerment to contextualize religious teachings within social life. This research used the qualitative method to describe and analyze the empowerment process, the obstacles during the process, and how religious values and critical analysis affect the empowerment process within pesantren and community. This study resulted in three main points. First, it showed that the stages of empowerment begin with raising critical awareness, analyzing social problems, identifying resources, and building community-based social institutions. Second, it also identified the main principle of empowerment, i.e., democratic, participatory, and community-need-based empowerment programs. Third, it indicated that community participation plays a role as the subject and pesantren as a facilitator of social empowerment.
\end{abstract}

Keywords: spirit of nationality, religious tradition, border society

\section{INTRODUCTION}

$\mathrm{T}$ The discourse on the concept of empowerment has developed very significant and increasingly attractive to researchers, academics, and practitioners. One of the interesting development is the fusion between the concept of empowerment and religious values. In Faith-based Organization (FBO), empowerment is interpreted as the manifestation of religious values. It is categorized into 'social worship' which means a form of Muslim obligation in social life as an effort to carry out God's commands and be accountable to God (Mahfudh, 1994; Widayanti, 2020). Likewise, the empowerment process carried out by the community and religious-based institutions has uniqueness and authenticity (indigenous) which enriches knowledge about empowerment.

In Indonesia, where most of the population is Muslim, empowerment with the community is closely related to religious practices. As part of the civil society movement, pesantren is one of the FBOs in the Indonesian Muslim community. Historically, pesantren is the first and oldest education system in Indonesia that integrates Islam and Indonesianism (Sindu Galba, 2013; Arif, 2008). There are at least three main elements in pesantren, namely Kiai (pesantren leader), santri (students studying with Kiai), and dormitories or boarding schools. In addition to carrying out the teaching and learning process at the pesantren, Kiai has a significant role in social relations. Most people believe that Kiai has the virtue of knowledge, so that they refer to Kiai to ask questions about religious issues and other social problems. The integration between the pesantren and the community has been built since the beginning of its' emergence, where pesantren inclusively accepts students from all levels of society (Bawani, 2011; Wahid, 2006). In this context, the role of pesantren 
goes beyond a religious education institution that studies classical books, tahfidz, and various other branches of religious knowledge. Pesantren also plays a role as a social institution involved in overcoming social problems and providing community services in various fields such as social, economic, health, education, and others (Azra, 1999).

In general, there are internal and external factors that underlie the implementation of empowerment activities in pesantren. Internal factors are related to the shifting paradigm of understanding community empowerment activities as part of worship and $d a^{\prime} w a h$, and their broad influence on the surrounding community. In this context, empowerment is interpreted limitedly as charity but rather as part of the pesantren's responsibility. Meanwhile, external factors are related to the increasingly complex social problems which are indicated by the increasing poverty rate and the low level of education, especially those living in rural areas.

Pesantren Maslakul Huda is a pesantren concerned with community empowerment activities as its manifestation to contextualize Islamic teachings within social life and carry out its function as a social community institution. Since 1979, these efforts have been carried out by mobilizing the community to establish financial, health services, environmental programs, and education. Pesantren and society set shortterm and long-term goals of the empowerment programs. The short-term goal is to produce village and pesantren cadres as community development teams and agents of social change by fostering and developing self-help groups that will utilize resources to meet physical and mental needs. Meanwhile, the long-term goal is to develop the community's creativity and productivity and pesantren through self-help and initiative development, create models for community development through pesantren, and preserve dialogue between pesantren and communities in development (BPPM, 2012).

Theoretically, the empowerment process aims to increase the power of individuals and communities by utilizing their capacity to deal with obstacles in the existing social system, and developing organizational or institutional schemes in various aspects such as economy, politics, culture and others.
Thus, the community members have a bargaining position in their social interactions locally, nationally, and internationally to improve welfare (Payne, 2005: 295). In this context, community empowerment is always associated with the concepts of justice, independence, and participation (Hikmat, 2004: 4). Concerning this, one of the biggest challenges in the pesantren's empowerment process is whether the empowerment is truly capable of empowering the community or it is only used as a new term to define old practices. The next question is what the stages of the empowerment process implemented by pesantren and the community to increase power and build community independence based on the values of democracy, equality and justice are. In other words, the main focus of this research is to describe and analyze the process of community empowerment, the role of pesantren as facilitators and community participation as the main actors in the process of increasing empowerment, independence, and the ability to overcome various social problems by managing potential and building community creativity to be independent economically, health, socially, culturally, politically, and others.

\section{Conceptual Framework}

\section{Social Empowerment}

Empowerment is an interesting concept related to its various definitions. First, Cattaneo dan Chapman articulates that "empowerment is an iterative process in which a person who lacks power sets a personally meaningful goal oriented toward increasing power, takes action toward that goal, and observes and reflects on the impact of this action, drawing on his or her evolving self-efficacy, knowledge, and competence related to the goal. Social context influences all six process components and the links among them" (Cattaneo \& Chapman, 2010: 647).

Figure 1. The Empowerment Process Model

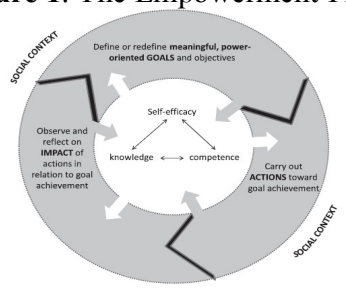

Source: (Cattaneo \& Chapman, 2010: 647) 
Second, Keiffer (1984 in Lord \& Hutchison, 1993) explains empowerment as a process that consists of four stages: entry, advancement, incorporation, and commitment. The entry stage is understanding the participant's experience of some event or condition threatening to the self and family, or an act of 'provocation'. In the advancement stage, there are three major aspects to continuing the empowerment process: a mentoring relationship, supportive peer relationships with a collective organization, and the development of a more critical understanding of social and political relations. The incorporation stage focuses on the development of political consciousness. The commitment stage, one in which the participants apply the new participatory competence to ever-expanding areas of their lives.

Third, empowerment is a continuous process throughout one's life (on-going process) (Adi, 2013: 212). In the context of social empowerment, the on-going process also applies, where empowerment will not end as long as the community is there and wants to try to empower themselves. He explains five stages of the empowerment process: (1) bringing back empowering and nonempowering experiences; (2) discuss the reasons why empowerment and disability occur; (3) identify a problem or project; (4) identify a meaningful resource base for making changes; (5) develop action plans and implement them. The description of the empowerment cycle is as follows:

Figure 2. Empowerment cycle

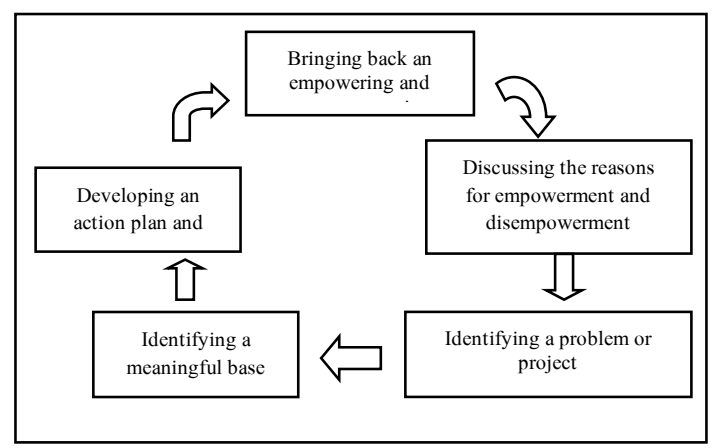

Source: (Adi, 2013: 213)

Moeljarto (Pranarka \& Moeljarto, 1996: 36) stated another opinion regarding the process of community empowerment, especially in the context of poverty reduction, which focuses on the critical awareness of society, liberation from domination and exploitation, and participation. The stages are: (1) increasing the critical awareness of the poor about their position in the socio-political structure in which the poor live; (2) efforts are made to break exploitative relations with the poor; (3) instill a sense of equality and explain the picture that poverty is not destiny but as an impact of social construction; (4) realizing the formulation of development by fully involving the poor; (5) the need for social and cultural development for the poor; and (6) a more equitable redistribution of development infrastructure is required.

Apart from the various thoughts and different stages in the empowerment process described above, these various views have in common that empowerment is a process that runs continuously and will never be completed in a circle through formulated stages to improve the power of person or society in social interaction. Dependence on other parties, such as the government or other institutions, will limit their movement to participate and voice their aspirations in the development process to improve their welfare.

\section{The Role of Actors in Social Empowerment}

Within the social empowerment process, the subjects of change or community workers or empowerment activists have four roles and skills, i.e., facilitative, educational, representative, and technical (Adi, 2013: 215; Ife, 1997). Related to the role of organizations as agents of change in community empowerment, Lin (Lin, 1998: 223) argues that an organization should have four elements, each of which greatly influences the effectiveness of the empowerment process, i.e., empowering leaders, empowering organizational culture, empowering management practices, and empowered employees and teams.

Figure 3. Organizational Model of Empowerment

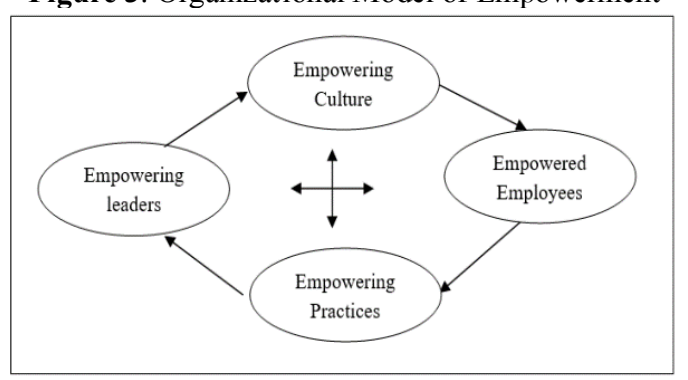

Source: (Lin, 1998: 224) 
This overview describes the main elements of an organization in carrying out sustainable empowerment. It is important to underline that these four elements are related to one another. For example, an empowering leader will encourage developing an empowering culture, design empowering practice patterns, and form self-managed work teams. An empowering culture will generate empowering leaders, accelerate the implementation of empowering practices, and build well-managed work teams. Empowering practices reinforce an empowering culture, demonstrate the resilience of an empowering leader, and encourage the work of an empowering team. An empowered work team will foster an empowering culture, encourage leaders to maintain and discover empowering practice patterns. Powerful work teams will also empower leaders in their work units, and this process will continue to the lowest level.

The explanation of the elements above is aimed to provide an overview of the organization's role in community empowerment. Developing empowered communities should be supported by empowered and empowering leaders, culture, management, and work teams. Without empowerment in the organizational work process described above, the formulated community empowerment scheme will not work. Thus, the empowerment process occurring within the organization will greatly affect the role of the organization and the effectiveness of wider community empowerment activities.

Pesantren is one of the faith-based organizations that initiates community empowerment in Indonesia. Pesantren's role as a cultural institution that uses Javanese cult ural symbols functions as 'a renewal agent' by introducing the idea of rural development; as a center of community learning activities; and as an Islamic educational institution that relies on the syllabi of Islamic studies as the basis of reference for traditional pesantren (Wahid, 2006). These roles are related to the main agenda of Islam as a social ideology to transform the existing conditions of society towards an ideal order. Thus, Islam is very concerned with social reality, not only to understand but also to change and control. At the theoretical level, transformative thinking seeks to build alternative social theories based on Islamic views. Whereas at the practical level, the main focus is on solving empirical problems such as poverty, neglect, violence, and social inequality (Kusmana, 2006).

There are four stages of the community empowerment process carried out by the pesantren, namely liberating and awakening the community, mobilizing community participation and self-help ethos, organizing education and producing knowledge, and pioneering how to approach problems correctly so that people recognize their real needs. The focus of empowerment activities is economic life, appropriate technology, health, the environment, and community education (Zubaedi, 2007: 240241).

The practices of pesantren-based empowerment are local, in which the pesantren can play a good role if it is associated with the changes within the structure of society itself. According to Wahid (2010, pp. 202-206), to carry out the fundamental social transformation, the target of change is not the government system or the political system, but in its subsystems by building a community that upholds the rule of law, is free from pressure, a framework democratic state and fair distribution of wealth. Those objectives can be achieved not through political channels but cultural campaigns by raising the community's awareness of their ability and potential to determine their destiny. The cultural approach is applied to develop socio-economic institutions and political awareness of the society's power to transform their lives. This is the strategic role of pesantren to make changes in society in the local context as an effort to improve the welfare of the community.

\section{RESEARCH METHOD}

In this study, the research method is applied to understand and explain the research process regarding the implementation of faithbased community empowerment. The social research method chosen is closely related to different views on how social reality should be studied (Bryman, 2008: 4). Therefore, in social research, the choice of method is not neutral. This study applied a qualitative method, where data collection was carried out by observation, in-depth interviews, group discussion, and documentation. A naturalistic 
approach was used to understand phenomena in context-specific settings, such as real-world settings [where] the researcher does not attempt to manipulate the phenomenon of interest (Patton, 2002: 39).

By applying this approach, the purpose of the research was to understand the process of faith-based empowerment experienced by community and pesantren who were currently involved in the struggle to become empowered. Specifically, the goals of the study were to:

1. Explore the stages of the faith-based empowerment process to increase the community's empowerment, independence, and ability to overcome various social problems by managing potential and building people's creativity to be economical, healthy, social, cultural, and political independence.

2. Analyze the community's participation as the subject of empowerment programs and pesantren as the facilitator within the process.

This research took place at the Pesantren Maslakul Huda Islamic, located in Kajen Village, Margoyoso District, Pati Regency, Central Java. This pesantren is one of the first Islamic boarding schools in Indonesia to carry out socio-economic empowerment activities for the poor in rural areas since the 1970s ((BPPM), 2012). The socio-economic empowerment in this pesantren is a transformation of the model of giving compensation to the poor, given at certain times, such as religious holidays, which have become a tradition for generations in Muslim societies. The idea of empowerment and its implementation process promoted by pesantren is based on a critical perspective in understanding religious texts and analyzing social problems faced by rural communities.

The frameworks of qualitative research and biographical analysis were used to guide the research process. All interviews were recorded and transcribed verbatim and supported by field notes (Patton, 2002). The next step is a coding process consisting of five stages: data sorting and classification, open coding, axial coding, selective coding, interpretation, and elaboration (Neuman, 2006). The coding process is carried out by finding keywords to identify similarities and variations and identifying patterns/sub- themes in data groups, then identifying themes that connect and explain the data.

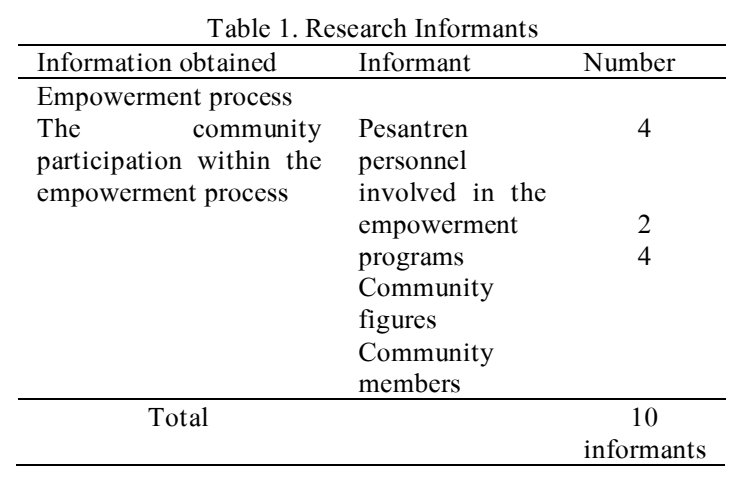

\section{DISCUSSION}

In this section, the process of social empowerment as described by the research participants is outlined. Common themes which emerged from the three groups (pesantren personnel involved in the social empowerment process, community figures, and community members) will be discussed. In addition, themes that illustrate differences amongst the groups will be reported. As the themes are presented, the findings will be linked to the literature. This integrated approach to research reporting is considered more meaningful when working with qualitative data.

The four main stages that emerged during the data analysis were:

1. Raising critical awareness,

2. Identifying social problems and their causal factors,

3. Identifying community's power to make changes,

4. Building community-based socioeconomic institutions.

This analysis seeks to find the uniqueness within each stage, as the implementation of the community's concept of empowerment based on their religious values.

1. Raising critical awareness

The first stage of the empowerment process is to raise critical awareness and increase insight into community development. This awareness and insight are the main elements of empowerment because they greatly influence the perspective and practice of empowerment. Raising critical awareness of the poor about their position in the sociopolitical structure they live in is the main point in community empowerment (Pranarka 
\& Moeljarto, 1996). Critically, people are educated to realize that their poverty is closely related to the existing practices of injustice systems and structures. In addition, they are also encouraged to realize that they can identify potentials and freedom to make decisions about their lives.

In an attempt to raise critical awareness within pesantren and society, the first step is to send pesantren cadres to community development training organized by non-governmental organizations (NGOs) who are concerned with the same issue. Pesantren openly collaborates with nonMuslim institutions and even from abroad. As stated by one of the informants as follows:

\begin{abstract}
“...kemudian pesantren juga ketika mendirikan BPPM, itu kita sekolahnya dengan orang Nasrani di daerah Magelang sana...jadi yang ndidik kita orang Nasrani. Ya karena kita harus punya ilmunya, ini kan masalah ilmu bukan amaliah keagamaan. Kita juga pernah mendatangkan guru di Matholi'ul Falah dan Maslakul Huda, gurunya Nasrani juga, orang Barat...jadi native langsung. Jadi kita sedemikian terbuka dalam masalah ini" (AW, Januari 2014).
\end{abstract}

("... then the pesantren also founded BPPM, we went to school with Christians in the Magelang area, so we learned from Christians. Yes, because we must know, this is a matter of knowledge, not a religious practice. We also brought in Christian teachers in Matholi'ul Falah and Maslakul Huda. We learned from them, although they were Westerners. We learned directly from natives. So we are so open in this matter")

Furthermore, the knowledge and critical awareness of the pesantren cadres are the capital to foster the same awareness in the community. Applying the cultural-spiritual approach, this effort is carried out through recitation groups (Yasin Tahlil). Furthermore, various training activities were held for the community continuously. The community group meeting is a means to discuss the community's ideas about their problems and solve them. Increasing the capacity of human resources, which includes critical awareness and skills training, is the first step in carrying out social transformation (Mullaly, 2002). In this context, the pesantren's efforts are an entry point for social transformation at the local level. As expressed by Wahid (Wahid, 2010), the empowerment practices carried out by pesantren are at the local level, and the target of change is the structure of the community itself.

2. Identifying social problems and their causal factors

Based on the problem identification in the Pesantren Maslakul Huda, the problems of Kajen society and its surroundings include economic, socio-cultural, and political that influence one another. Identifying those problems is closely related to the awareness of the pesantren and the community in understanding social reality. In this context, critical awareness encourages them to analyze social problems comprehensively. The pesantren's main concern on community's problems as the basis for determining the empowerment programs also indicates the pesantren's alignments to the community.

\section{a. The Problem of Economy}

The economic problems of Kajen society are not only identified by their low level of income but also associated with their inability to access education and the people's houses which are characterized by thatched roofs and dirt floors.

“...jika melihat permasalahan orang desa di sekitar pesantren -di mana umumnya pesantren berada di daerah pedesaan- kita akan menyaksikan betapa kompleksitas permasalahan mereka. Mulai dari pendapatan yang rendah, ketidakmampuan untuk membiayai pendidikan anak...." (AS, 1999: 8)

(“... If we look at the villagers' problem around the pesantren-where most of the pesantren are in rural areas- we will see how complex their problems are. Starting from low income, inability to pay for children's education...")

\section{b. The Problem of Socio-cultural}

The socio-cultural problems are analyzed from the informants' identification of several problems, including the difficult access to public health services. Before empowerment was carried out, not many people could access Puskesmas, the public 
health service provided by the government. In addition, the local government's attention to the health of children under five and pregnant women is not yet available for the village community. The second problem relates to the people's assumption that this is an unchangeable condition because it has been going on for generations. Thus, this assumption will lead to a culture of poverty.

\section{c. The Problem of Politics}

The identification of political problems at the Pesantren Maslakul Huda can be analyzed from the way they relate social problems to injustice practices in the policies and programs of development. They viewed that the root causes of poverty and social problems are the injustices of economic, political, and cultural systems and structures. This is as explained by the Kiai of Pesantren Maslakul Huda in his writing as follows:

\section{“....ketidakberdayaan untuk mendapatkan hak-hak yang asasi, hingga ketertindasan mereka ketika berhadapan dengan kekuatan yang lebih besar (AS, 1999: 8).}

(... powerlessness to obtain human rights, to their oppression by the dominant groups).

In this context, people are not regarded as part of the existing problem, but they are victims of these unfair systems and structures. However, in contrast to Fakih's view (Fakih, 1996) the form of intervention based on critical awareness is social action, pesantren quite the opposite views that making changes to society's condition is building community-based institutions in the local context.

In identifying the causal factors of these problems, pesantren and the community have a critical awareness to link their analysis to the system's problem and structural injustice (Fakih, 1996; Mullaly, 1997). First, in one of the pesantren's documentation, it was revealed by santri alumni, that structural factors are the main cause of impoverishing society through a systematic process:

"Ironically, the poverty is not caused by natural factors, but rather structural. Historically, since the New Order era, the State's excessive suspicion of Islam has marginalized every form of community participation, both politically and socially. As a result of the treatment, economic access for Indonesian Muslims automatically becomes very limited. The impoverishment of Muslims is carried out systematically. Instead of making the people prosperous, the State deliberately torments the people" (Pesantren Document, 2012).

The second, the development gap. Almost all informants from the pesantren have the same view regarding the development gap that impacts the impoverishment of rural communities. As stated by one informant follows:

“...kan perbandingan dulu dengan sekarang
namanya program, program pemerintah kan
tidak merata, jelas tidakmerata. Pada waktu
itu (hanya) daerah-daerah tertentu yang
mendapatkan bantuan atau perhatian dari
pemerintah...dari pesantren juga bantuan,
pelatihan juga ada. Saya katakan begini,
dulu kok melakukan pengembangan
masyarakat bisa segitu getol dan diterima
masyarakat, itu karena tadi, pengembangan
di tingkat pemerintah pusat atau daerah itu
ada kesenjangan" (AH, Januari 2014)

("since a long time ago, the development program is not, obviously not even. At that time, (only) certain areas received assistance or attention from the government... the pesantren program is giving assistance and training for the society. I say this, how did community development worked so hard and was accepted by the community?, as I said earlier, there are gaps in the development program from the central or regional government")

Third, policies that side with the dominant group and are detrimental to society. According to informants, the government's policies were not pro-poor but only benefited certain groups. The national budget that should be used to build infrastructure in the regions, in fact, is not being implemented optimally. As a result, the infrastructure built was not as planned.

Fourth, leaders who are more concerned with their personal interests than society. Apart from the injustice in the development structure, the informants also criticized the characteristics of the politicians who prioritize their interests and pay less attention to the community's interests as the beneficiaries of development. In addition, 
although there is a religious belief in one's destiny, in this case, the government is responsible for the poverty experienced by its people.

"...yo itu tadi lho, karena pemerintah itu tidak, tidak memahami yang dikejar hanya politis kemungkinan, unsur pokok yang ada di masyarakat itu terabaikan, bahkan yang berhubungan dengan pemerintah itu dimanfaatkan untuk kepentingan mereka yang memegang jabatan..." (AH, Januari 2014)

("...since there are politicians who do not understand, they only pursue their political interests, the main elements in society are neglected.")

3. Identifying the community's power to make changes

The process of resource identification is highly related to the social context in Kajen Village. There are four categories of community power, i.e., social capital, spirit ual capital, human capital, and financial capital. All of these capitals are very influential in the sustainability and success of the empowerment process.

a. Social Capital

The identified social capital includes the potential of the community and pesantren which are both very important in shaping social capital for the empowerment process. The first potential is Kajen Village, which is known as a santri village because this village is one of the centers for the spread of Islam in Pati area, which is indicated by the number of Islamic boarding schools and religious schools. The existence of these pesantren leads to many santri/students who come from various regions to study. This condition has been identified as having an influence on the amount of money circulation in Kajen Village and is one of the potentials for the community to increase income.

The second potential is the strong public trust in the Kiai. One of the peculiarities of the relationship between pesantren and society is the existence of a strong belief in society to refer to the Kiai 's view of problems in all aspects of life. This trust is one of the assets for community acceptance of the idea of empowerment promoted by pesantren. In the political context, pesantren Maslakul Huda does not take advantage of public trust as a political commodity. Pesantren has a strong commitment not to get involved in practical politics. Thus, public trust as social capital is truly utilized for the benefit of society.

b. Spritual Capital

Faith is identified as the main foundation for community empowerment, where the estuary of all human efforts in living is Allah SWT. In this context, empowerment is believed to be a form of social worship to manifest Islamic teachings as rahmatan lil'alamin.

c. Human Capital

The identification of pesantren for human capital can be seen from mapping diverse community expertise following their natural potential. The mapping was carried out to determine the community's need to increase their existing skills or acquire new skills they wanted. Furthermore, these various skills become the basis for determining empowerment programs. In addition, pesantren Maslakul Huda also identifies Kiai, alumni, and students as agents of empowerment. They have a direct role in working with the community, using a cultural approach through groups of Yasin tahlil and women's groups.

d. Financial Capital

In managing financial capital, the uniqueness possessed by the pesantren Maslakul Huda is an effort to eliminate community dependence on various forms of social assistance and loan offerings from loan sharks, which is carried out with several strategies. First, funds are routinely collected from the community and managed in groups independently. The fund is used as a capital loan for group members in rotation to develop their business. Second, pesantren manages funds from training and research packages conducted in collaboration with government and non-government agencies. The management of these funds is used to pay the pesantren staff who are involved in community assistance. In this case, the pesantren tries not to depend on funds from other parties to maintain the sustainability of empowerment activities. Third, the source of funds comes from managing funds for social assistance programs to become the capital for economic development. In this context, pesantren invites the community to utilize 
social assistance as a capital for empowerment jointly. This effort is carried out to prevent community dependence as well as foster selfreliance within them. Fourth, funding sources are obtained from cooperation in various government programs entrusted to be managed by pesantren for empowerment. Fifth, the pesantren's efforts to build profit and non-profit institutions have also become sources of financial capital for community empowerment.

\section{Building a Community-Based Socio-} Economic Institution

The fourth stage of the empowerment process is building community-based institutions. The data shows that the community institutions are establishing an operational institution for empowerment, community group of savings and loans, community access to financial capital, and community access to education and health. The establishment of these accesses is based on the community's needs to raise independence, self-sufficiency, and the ease of fulfilling health, education, and economic rights based on Islamic values. The explanation regarding the establishment of socio-economic institutions in implementing empowerment at the pesantren Maslakul Huda in more detail is as follows.

\section{a. Building Operational Institution}

In an effort to optimize the role of pesantren in community empowerment, pesantren established operational institutions, Badan Pengembangan Pesantren dan Masyarakat (BPPM) to organize empowerment programs for the community and (koperasi pesantren) pesantren's cooperatives that provide economical access for community business capital. The establishment of this institution was motivated by the idea that the existence of pesantren should provide benefits that can be felt directly by the surrounding community, especially socio-economic benefits.

In this case, BPPM is a specific institution dealing with community empowerment activities so that the management is separated from the pesantren which focuses on education. Meanwhile, the cooperatives that were established also have different characteristics from the cooperatives in other pesantren or the same cooperatives in general. In this case, the pesantren's cooperative was not a store that provides the daily needs of the santri, arguing that these grocery stores were part of the community's rights around the pesantren. This is one form of implementing the idea that pesantren should provide direct economic benefits to the surrounding community. According to this view, pesantren cooperatives should not participate in the community or turn off their businesses by establishing similar businesses. On the other hand, the cooperative must support the development of these community businesses by building business units that support community businesses, one of which is the sharia savings and loan unit, which provides access to capital for community members.

\section{b. Building a Group Savings and Loans Business}

Based on the data obtained, the practice of empowerment in the economic sector raises public awareness and eliminates their dependence on social assistance. These efforts are carried out by implementing several strategies. First, pesantren encourages community groups to set up savings and loan businesses with capital collected from their members. The collected capital is then lent in turn to group members without interest. The second strategy is for pesantren to cooperate with other parties to provide capital loans under a joint responsibility system. This system aims to foster joint responsibility of group members and encourage them to support each other's business development.

\section{c. Building Access to Capital}

The third strategy is to introduce an administrative system for community group savings and loans. This system was chosen as an alternative to develop group savings and loan capital because the loans granted do not apply interest. As applied in the agricultural sector, the next strategy, pesantren collaborates with communities who own agricultural land using a production sharing system. In this program, the pesantren provides plant seeds and fertilizers to landowners, while they are responsible for caring for and maintaining them. The application of the profit-sharing is carried out by agreement after the agreed period so that the whole agricultural business belongs to the 
community. The final strategy adopted by the pesantren is to establish financial institutions, in this case, the Bank Perkreditan Rakyat (BPR) and Bank Perkreditan Rakyat Syariah (BPRS) which aim to provide access to capital for rural communities who according to the existing banks are not bankable. Based on these data, the main characteristic of the empowerment implementation carried out by Islamic boarding schools in the economic sector is building an alternative economic system for the community (Fakih, 1996:122).

\section{d. Building access to pesantren and higher education in villages}

In education, pesantren, with their critical awareness, strives to provide access to education from the basic level (Madrasah Ibtidaiyah) to Senior High (Madrasah Aliyah) for the rural poor. In addition, efforts to empower students are also carried out by implementing an education system that builds the character of empowered students. At the Maslakul Huda, the presidium system is implemented by building an organization where students are responsible for managing all their own needs, including budget ary needs and subject matter. With this system, the Kiai expects the pesantren to become a miniature of society, where students can learn to work together and socialize with each other. Another program included in empowering the education sector is establishing a higher education institution (Islamic College Matholi'ul Falah / STAIMAFA) in villages to provide access to higher education for people in rural areas.

\section{e. Building Community Based Health Access}

In the health sector, implementing the empowerment program is closely related to the community context when the empowerment began. In the 1970s, access to health was one of the main needs of the people of Kajen Village, given the very limited health facilities provided by the government for rural communities. This need underlies the idea of the pesantren together with the community to establish a (pos obat) medicine post for the community and (pos kesehatan) a pesantren health post for students. Regarding human resources in the health sector, pesantren and community cadres collaborate with government health institutions to hold training in the health sector. In its development, currently in Kajen Village, a hospital has been established which is a development of the medicine post and health post.

\section{Community as Subject of Empowerment and Pesantren as the Facilitator}

Based on the data analysis, there are three main characteristics of implementing the social empowerment process carried out at the Pesantren Maslakul Huda, i.e., democratic, participative, and the program determination based on the needs of the community.

\section{a. Democratic principles}

In the planning of empowerment programs and their implementation, an obvious characteristic is democratic principles. This principle can be seen from the viewpoint of the pesantren, that society has potentials that must be developed through providing opport unities to learn to identify social problems faced, identify potentials that can be used as empowerment assets, and train them to be able to make choices and make decisions for themselves. In this context, pesantren highly value the strength of the community capacity by facilitating the activities needed to increase their awareness of their potential and rights through community development training.

Second, the Kiai of the pesantren has never ordered or determined empowerment activities that are not a mutual agreement between the pesantren and the community but was open to providing direction when needed. Even in this case, the Kiai did not immediately provide answers to the problems posed; instead, they asked the community what should be done to stimulate their creativity. This principle was also applied in the case of the education system in pesantren, where the Kiai strongly believed in the students' idea and their activity plans.

Third, the pesantren provides opportunities for the community to benefit from the students' existence by establishing food stall businesses that provide the daily needs of the students. In fact, pesantren is trying to support community business development by establishing various business units such as pesantren cooperatives that aim to provide easy access to capital. In this context, pesantren do not seek to dominate 
the economic benefits of pesantren but instead see them as potentials that the community can utilize to increase their income.

\section{b. Participative principles}

This second characteristic can be seen from the pesantren's efforts to involve the community in all empowerment processes. Starting with the process of forming groups, the pesantren approaches the community through informal figures consisting of religious and traditional leaders who are trusted by the community. In this process, the pesantren deliberately does not involve formal figures to aim that those involved are those who do not have certain political interests because they are feared that they will conflict with the pesantren's goal of empowering the community. Since the beginning, the community leaders involved were given awareness that the formation of community groups was carried out for empowerment, not for other reasons such as obtaining social assistance. In this context, the pesantren involves community leaders in the formation of community groups.

In addition to that, participation can also be seen from the pesantren's efforts to hold regular meetings attended by community groups with assistance from the pesantren as facilitators. In these meetings, the community is encouraged to express ideas related to group activities and deliberate to determine the steps to be taken in solving the problems they face. This dialogue is one way to increase public confidence by respecting their rights and competencies to make decisions regarding themselves(Fetterman et al., 1996).

\section{c. The Program Determination Based on The} Needs of The Community

The Pesantren Maslakul Huda based the planning and implementation of empowerment programs on community needs. This is evidenced by community involvement since the initial identification of problems and potentials, planning empowerment programs, implementation, and continuous evaluation. In this case, the pesantren takes more of the role of facilitators and assistants to community groups and establishes operational institutions that can support community businesses.
The empowerment that "truly empowers" shows that the role of the community is bigger than the role of the pesantren in the socio-economic empowerment process. In this context, the community is given space to assess the problems and their potential to be utilized in poverty reduction programs. The main role of pesantren in the initial empowerment process is to become a facilitator for critical awareness in society.

They have the right and freedom to make choices about their lives. Furthermore, the community is assisted by the pesantren to form groups and deliberate in making decisions and planning programs. If the selected program requires certain skills or skills community members do not possess, the pesantren will facilitate them to acquire or improve the skills needed (Lin, 1998). These efforts are carried out by cooperating with other parties, both government and nongovernment, who have the same concern about community empowerment.

The main role of the community in making decisions and making choices for the efforts made shows that the socio-economic empowerment program is based more on the needs of the community than the needs of the pesantren. The effort made by the pesantren is to facilitate the community to build community-based institutions in various fields jointly. Thus, religious values and strong community trust in pesantren are benefited to empower the community.

\section{Constraints in the Implementation Process of Empowerment}

The identification of the obstacles faced in the initial empowerment process is closely related to the socio-political context of the 1970s, where the political sit uation did not support the existence of community movements. In the context of community empowerment, the pesantren came under pressure from the government, which severely limited the space for NGOs, including pesantren. Second, obstacles also came from the community and other pesantren, which at that time still held the view that the idea of community empowerment was not part of the pesantren's responsibility.

The third obstacle is related to the social conditions in the last few years, where 
many government policies have provided various forms of direct assistance to the community. This assistance is provided as part of social protection programs, but their impact leads to the community's dependence on social assistance. This is a tough obstacle for the empowerment movement because efforts to get the community together to increase independence and self-reliance are becoming increasingly difficult.

\section{CLOSING}

Based on the discussion, it can be clearly seen that pesantren has a significant role in social empowerment. It is not only an institution which teaches people religious teachings and dogmas but also helps them to get a better life in various fields such as economic, political, financial, and health. Pesantren Maslakul Huda was a pesantren that helped society get such a better life by providing them with several actions. The pesantren conducts at least four stages to implement social empowerment. It starts with raising critical awareness and ends up with building a community-based socio-economic institution. In the whole stages, the pesantren helps them be aware that the community's bad condition is not an absolute destiny which could not be changed into better. Such an unfortunate situation is changeable if people recognize the root problems and their own potentials. Therefore, they need to create a culture, find empowering leaders, and make teamwork that becomes a supporting system to change the situation better.

In terms of identifying root social problems, the pesantren helped connect the condition with something outside. By the outside people here is factors coming from outside Kajen's community. The pesantren and people then found three main surroundings-pesantren-community social problems (economic, socio-cultural, and politics), mainly caused by injustice system and structures. They are structural factors, development gap, policies taking a side on the dominant group, and leaders concerning more on their personal interest than society. By identifying these basic social problems and their causal factors, it is clear that the Pesantren Maslakul Huda saw the community as the victim of a vicious circle. Therefore, the pesantren pushed them to find their potentials or their own capital to make their lives better.
After analyzing their potentials, the pesantren and the community found four major capitals which are closely related to pesantren. The pesantren itself, surroundingpesantren tradition, the santri, the alumni, and the Kiai are the capitals to make social empowerment; even the last three mentioned parties were main agents of empowerment. These capitals were then utilized and empowered to build community-based socioeconomic institutions. There were five kinds of different institutions built according to Islamic values to get various accesses: economic and financial, capital, education, and health.

The second important finding of this study is the role and the position of the pesantren and community in the whole process of empowerment. Although the pesantren Maslakul Huda was a respected institution with its various aspects, it did not take a dominant position in which pesantren is superior to the community. Otherwise, the pesantren took a role as a facilitator while the community is the main actor in the process of empowerment. This position could be seen from the principles run during the empowerment: democratic, participative, and program determination. By applying these three principles, Kiai as a very significant figure in pesantren, for example, even in some sources, he is described as a figure who almost all people are subject to his words, never gave direct instruction in determining empowerment programs. He never gave a direct answer to problems posed by the communities instead of asking and discussing what they should do to overcome the problems. The empowerment programs were designed based on the need of the community. It is the people who have to identify their needs and decide the programs suitable to their needs.

The last finding of this study is the obstacles faced in social empowerment. The Pesantren Maslakul Huda faces at least three main constraints in empowering the surrounding community. The first is sociopolitical-context remains in the 1970s in which government was not supportive of empowerment, even when pesantren was under pressure. The second is a perspective of some people and some other pesantren who said that social empowerment was not pesantren's responsibility. The third is 
community dependence on the government's social assistance. Finally, to make it easy to understand peculiarities and characteristics of the empowerment process carried out by the Pesantren Maslakul Huda, figure 4 is presented.

\section{ACKNOWLEDMENT}

The author would like to thank all those who contributed to this research. In particular, thanks to all the editors of the journal Al-Qalam Makassar Research and Development Institute for Religion who published this paper.

\section{REFERENCES}

(BPPM), B. P. P. \& P. M. (2012). Pesantren Maslakul Huda.

Adi, I. R. (2013). Intervensi Komunitas dan Pengembangan Masyarakat: Sebagai Upaya Pemberdayaan Masyarakat. Rajawali Press.

Arif. (2008). Pendidikan Islam Transformatif. Lkis.

Azra, A. (1999). Esei-esei Intelektual Muslim Pendidikan Islam. Logos Wacana Ilmu.

Bawani, I. (2011). Pesantren Buruh Pabrik: Pemberdayaan Buruh Pabrik Berbasis Pendidikan Pesantren. Lkis.

Bryman, A. (2008). Social Research Methods (3rd ed.). Oxford University Press.

Bungin, B. (2007). Penelitian Kualitatif: Komunikasi, Ekonomi, Kebijakan Publik dan Ilmu Sosial lainnya. Kencana Prenada Media Grup.Cattaneo, L. B., \& Chapman, A. R. (2010). The Process of Empowerment: A Model for Use in Research and Practice. American Psychological Association, 65.

Fakih, M. (1996). Masyarakat Sipil untuk Transformasi Sosial: Pergolakan Ideologi LSM Indonesia. Pustaka Pelajar.

Fetterman, D. M., Kaftarian, S. J., \& Wandersman, A. (1996). Empowerment Evaluation: Knowledge and Tools for Self-Assessment\&Accountability. Sage Publication.

Ife, J. (1997). Rethinking Social Work towards Critical Parctice. Longman.

Kusmana. (2006). Islam dan Kesalehan Sosial: Relevansi Al-Qur'an tentang Filantropi dalam Pengembangan Masyarakat. In Kusmana (Ed.), Bunga Rampai: Islam dan Kesejahteraan Sosial. IAIN Indonesian Equity Project.

Lin, Y.-Y. (1998). The Essence of Empowerment: A Conceptual Model and A Case Illustration. Journal of Applied Management, 7(2).

Lord, J., \& Hutchison, P. (1993). The process of empowerment: Implications for theory and practice. Canadian Journal of Community Mental Health, 12(1), 522. https://doi.org/10.7870/cjcmh1993-0001

Mahfudh, S. (1994). Nuansa Fikih Sosial. Lkis.

Mullaly, B. (1997). Challenging Oppression: a Critical Approach to Social Work. Oxford University Press.

Mullaly, B. (2002). Structural Social Work: Ideology, Theory and Practice. Oxford University Press.

Neuman, W. L. (2006). Social Research Methods: Qualitative and Quantitative Approaches (6th ed.). Pearson.

Patton, M. Q. (2002). Qualitative Research and Evaluation Methods. Sage Publication.

Payne, M. (2005). Modern Social Work Theory (3rd ed.). Palgrave Macmillan.

Pranarka, A. M. W., \& Moeljarto, V. (1996). Pemberdayaan (Empowerment). In O. S. Prijono \& A. M. W. Pranarka (Eds.), Pemberdayaan: Konsep, Kebijakan dan Implementasi. CSIS.

sindu Galba. (2013). Pesantren Sebagai Wadah Komunikasi. Renika Cipta, 6(2), $145-158$.

Wahid, A. (2006). Islamku, Islam Anda, Islam Kita: Agama Masyarakat dan Negara Demokrasi. The Wahid Institute.

Wahid, A. (2010). Menggerakkan Tradisi: Esai-esai Pesantren. Lkis.

Widayanti, S. (2020). Pesantren and Social Empowerment: A Critical Analysis On Pesantren Al-Imdad Yogyakarta And Pesantren Maslakul Huda Central Java. Analisa: Journal of Social Science and Religion, 5(01), 51-70. https://doi.org/10.18784/analisa.v5i1.10 55

Zubaedi. (2007). Wacana Pembangunan Alternatif. Ar-Ruzz Media. 
